\title{
"Knowing What It Is like": Dialoguing with Multiculturalism and Equity Through Collective Poetic Autoethnographic Inquiry
}

\author{
Kathleen Pithouse-Morgan \\ University of KwaZulu-Natal \\ South Africa \\ Inbanathan Naicker \\ University of KwaZulu-Natal \\ South Africa \\ Daisy Pillay \\ University of KwaZulu-Natal \\ South Africa
}

\begin{abstract}
We offer an account of how we, a research team of three South African academics, have dialogued with multiculturalism and equity through collective poetic autoethnographic inquiry. The focus of the article is on our learning through reading and responding to published autoethnographies by three other South African academics. We share our learning about how poetry and dialogue can facilitate a generative entanglement with autoethnographies written by others. The article highlights the promise of collective poetic autoethnographic inquiry for opening up spaces for dialoguing with multiculturalism and equity.
\end{abstract}

KEYWORDS: collective autoethnography, dialogue, equity, multiculturalism, poetic inquiry

Putting Ourselves in the Picture Our Shared Interest in Self-Reflexive Research Methodologies

Composing Research Poems Reflexive Dialoguing with the Renga Poem Composing an Interpretive Poem

Closing

Acknowledgements

Notes

References

Author Contact

In this article, we offer an account of how we, a research team of three South African academics, have dialogued with multiculturalism and equity through collective poetic autoethnographic inquiry. The focus of the article is on our learning through reading and responding to published autoethnographies by three other South African academics, Delysia Norelle Timm (2016), Robert J. Balfour (2016), and Rose Richards 
(2016). Our purpose in writing this article was to deepen our understanding of how we might learn collectively from reading other academics' autoethnographies.

We explicate our collective poetic autoethnographic inquiry process. To begin, we offer a brief portrayal of ourselves as a diverse South African research team. Next, we describe our shared interest in collective poetic autoethnographic inquiry as a creative, self-reflexive research practice. We then explain and present how we cocomposed three tanka poems ${ }^{1}$ as representations of our reading of the three autoethnographies, as well as a renga poem, ${ }^{2}$ which assisted us in synthesizing the three tankas. Stemming from our collective composition of the renga, we then present a series of dialogues to articulate our learning in relation to this poem. We go on to show how we developed a final tanka to crystallize our learning through collective poetic autoethnographic inquiry. To close, we reflect on the potential of collective poetic autoethnographic inquiry to create spaces for dialoguing with multiculturalism and equity.

\section{Putting Ourselves in the Picture}

We are based in a school of education at a South African university where we research and teach in the academic specializations of Teacher Development Studies (Daisy and Kathleen) and Educational Leadership and Management (Inbanathan). As a research team, we are diverse in terms of gender, cultural heritage, and race. This diversity is noteworthy given South Africa's history, in which "the strategies of the apartheid state...locked doors between people and denied them access to each other's experience" (Haarhoff, 1998, p. 10). It is also personally meaningful for us, having grown up under apartheid in the fragmented spaces (educational, geographical, social, and so on) prescribed for people classified as Indian (Daisy and Inbanathan) and White (Kathleen). Having lived under apartheid, we do not take our research partnership for granted. We are aware that if we had been born some years earlier we would probably never even have met each other, let alone worked together on projects that bring us satisfaction and joy.

Apartheid is an Afrikaans word that can be translated as "separateness." In the apartheid era (1948-1994), the Nationalist government used the racial classifications of African, Colored, Indian, and White to separate and oppress South African people (Clark \& Worger, 2016). "African" referred to people who were understood to be indigenous to Africa, "Indian" referred to people who were understood to have ancestral heritage from India, "Colored" referred to people who were understood to be of "mixed race," and "White" referred to people who were understood to have ancestral heritage from Europe. A hierarchy of racialized privilege resulted in people designated as White benefitting from disproportionately greater government spending and having access to superior facilities and resources in all spheres of life, while people designated as African, Colored, and Indian were disenfranchised and relentlessly disadvantaged in innumerable ways (Clark \& Worger, 2016). 
Although race was the most obvious category used to circumscribe people's lives, the tentacles of separateness and discrimination were all-encompassing, with gender, sexuality, and ability/disability being among the many taxonomies used to disconnect and stratify South Africans (South African Human Rights Commission, 2012). This "failure to recognize the humanity of others and therewith, the others' entitlement to being treated with dignity is part of the legacy of apartheid" (p. 17) and continues to constrain the lived experiences of many South Africans, despite human dignity, equality, and the advancement of human rights and freedoms forming the "very first founding provisions of [post-apartheid] South Africa as a constitutional democracy" (p. 6).

\section{Our Shared Interest in Self-Reflexive Research Methodologies}

For the past five years, we have chosen to work together on educational research projects because of our shared interest in self-reflexive research methodologies, such as self-study of professional practice (Pithouse-Morgan et al., 2015), narrative inquiry (Pithouse-Morgan, Naicker, Pillay, Masinga, \& Hlao, 2016), and autoethnography (Pillay, Naicker, \& Pithouse-Morgan, 2016). In our understanding, selfreflexive methodologies are connected by a common focus on acknowledging, questioning, and reimagining the lived experiences and self of the researcher. We see autoethnography as a self-reflexive research genre in which the multifaceted, contingent self of the researcher becomes a lens through which to study interrelationships between personal histories, lived experiences, and wider sociocultural concerns (Chang, 2008; Grant, Short, \& Turner, 2013; Mitchell, 2016). Collective or collaborative autoethnography (also known as co/autoethnography) involves "study of self [that is] conducted in the company of others [and that] can be a catalyst to understanding group culture" (Chang, Ngunjiri, \& Hernandez, 2013, p. 17). As Coia and Taylor (2009) explain, "the collaborative analysis of our [lived] experience" through co/autoethnography is premised on a conceptualization of self that is not only "complex and culturally informed" but also "dialogical" (p. 3).

Chang et al. (2013) identified poetry as one of the "creative literary genres" that can be used for "imaginative-creative writing" to "express autobiographical experiences" in autoethnographic research (pp. 124-125). Similarly, in a literature review of the contemporary use of poetry in qualitative research, Lahman et al. (2009) described how "autoethnographic poetry has been composed by researchers to reveal some experience of the researcher, shedding light on aspects of life pulled from personal experiences that would not traditionally be considered data" (p. 40). Furthermore, qualitative researchers have demonstrated how, in addition to serving as autoethnographic data, poetry can be an alternative, creative mode for representation and analysis of autoethnographic data (Furman, 2005; Furman, Langer, \& Taylor, 2010).

Collective poetic inquiry is a research practice that we have been developing for several years in our work with academic colleagues who share our interest in selfreflexive research (Pithouse-Morgan et al., 2014; Pithouse-Morgan et al., 2015; 
Pithouse-Morgan et al., 2016). We have discovered that engaging in an intensive, creative process of co-composing and co-analysing poems can enrich and nuance our communication and meaning making as a research team and can contribute to the development of collective reflexivity, which we have characterized as "co-flexivity" and described as "being reflexive together through thinking deeply about and questioning our professional practice and selves in dialogue with significant others" (PithouseMorgan et al., 2015, p. 148). Something that we have realized through our collective, self-reflexive research is that we have connected and got to know each other and ourselves in new ways because of our shared explorations of our lived personal and professional experiences (Pillay \& Pithouse-Morgan, 2016). This realization is congruent with the Southern African ethical philosophy of ubuntu (in the Nguni languages), or botho (in the Sotho and Tswana languages), which expresses self or humanness in terms of relational and dialogic processes of becoming and in terms of an ethic of care for others (Harrison, Pithouse-Morgan, Conolly, \& Meyiwa, 2012; Mkhize, 2004; Reddy, Meyer, Shefer, \& Meyiwa, 2014).

\section{Composing Research Poems}

Our collective poetic inquiry process for this article was triggered when we read the IJME Special Issue Call for Papers on the theme of "Critical Autoethnography in Pursuit of Educational Equity." We looked again at the autoethnographies by Timm (2016), Balfour (2016), and Richards (2016) to consider how we might learn from them with respect to multiculturalism and equity. Our purpose was to deepen our understanding of how we might learn autoethnographically from our fellow academics' stories of contending with discrimination and marginalization due to being "othered" as Colored (Timm, 2016), gay (Balfour, 2016), and having a chronic disease (Richards, 2016). In selecting these three autoethnographies, we were guided by our understanding that issues of multiculturalism and equity are applicable in any case where being regarded as "other" undermines human dignity, equality, or the advancement of human rights and freedoms (South African Human Rights Commission, 2012).

Delysia Norelle Timm's autoethnography, From Exclusion through Inclusion to Being in My Element: Becoming a Higher Education Teacher Across the ApartheidDemocratic Interface (2016), illustrates how the apartheid legislation of the Nationalist government excluded the majority of South Africans from quality education on the basis of their racial classification. Through "self-reflexive relational autoethnography," Delysia explored how her lived experiences of educational exclusion as a Colored woman during apartheid constrained her academic choices and growth (p. 96). The autoethnography includes disturbing documentary evidence of Delysia's legislated exclusion from fair access to higher education on the grounds of race. It also offers insight into how Delysia's experiences of educational exclusion impacted adversely on her self-worth and self-esteem, on her preparedness for higher education, and on her aspiration to study Pharmacy. As Delysia articulated, "I felt angry. I was rejected. I was 
excluded. I was horrified and deeply hurt. I was just not good enough!" (p. 100). She went on to explain:

My lived experience of not believing in myself and being excluded is deeply rooted in the apartheid system of education.... believe we are experiencing a legacy of apartheid that has negatively influenced the education and living conditions of both teachers and students....The continued loss of belief in themselves, and mental and emotional pain leads to a lack of joy, a lack of love, and a lack of learning in the classroom. (pp. 111-112)

On a more optimistic note, the text concludes with Delysia's consideration of how her emotionally risky autoethnographic "retracing [of the] pain and brokenness" (p. 113) of educational exclusion has nourished her growth as an academic who values and strives for inclusion, equity, and social justice.

Robert J. Balfour's autoethnography, titled The (In)visible Gay in Academic Leadership: Implications for Reimagining Inclusion and Transformation in South Africa (2016), looks at equity through the eyes of a gay leader in academia. This autoethnography problematizes academic leadership in a post-apartheid South Africa in which rights do not guarantee acceptance. It highlights how, notwithstanding legal and constitutional prescripts that prohibit discrimination on the basis of sexual orientation, fair treatment of the LGBTTIQ (lesbian, gay, bisexual, transgender, transsexual, intersex, and queer) community is still to be realized in practice. In his autoethnography, Robert drew attention to how the possibilities for LGBTTIQ people to be viewed as role models, let alone effective leaders, remain elusive. As he explained, "Identifying as gay in (academic) leadership is rare but also risky" because of prevalent "heterosexist perspectives on role modelling" and "few provisions for spaces that are considered safe or LGBTTIQ friendly" (p. 135). Through the lens of autoethnography, Robert explicated his understandings and experiences of leadership in relation to inclusion and transformation while serving as an academic leader in three higher education settings. For instance, he recounted:

I was approached by another leader to offer a workshop on transformation, diversity, sexuality, and disability in the workplace....The vice-chancellor supported the workshop by inviting student and academic leadership. Yet, on the day, the workshop was full with mostly administrative staff, with only one black woman leader present. It seemed that the workshop (and by implication myself) was irrelevant to the leaders for whom it was intended. (pp. 143-144)

Robert's autoethnography shows how the experience of feeling insignificant and sidelined can lead to the erasure of identity and how contextual factors modify a subjective understanding of leadership as transformation in relation to institutional values. Robert concluded by reflecting on LGBTTIQ (in)visibility in academia with a view to reimagining possibilities for academic leadership. He argued that "LGBTTIQ people do bring experiences and understandings of difference...that can be used to better develop intellectual, social, economic, and indeed political leadership for all South Africans" (2016, p. 145).

In Rose Richards' autoethnography, Subject to Interpretation: Autoethnography and the Ethics of Writing about the Embodied Self (2016), she inquired into her 
embodied experience of chronic kidney disease after years of being othered and silenced. Rose recounted how she had felt "muzzled by other people's narratives of how [her] life should be" and highlighted the discrimination and marginalization she had experienced because of the disease (p. 163). She went on to explain:

Because people experiencing illness or disability are so often spoken about, not to, nor listened to, I am an extremist when it comes to hearing the voice of the person who experiences the illness or disability, and I went to the extreme when doing my research about the experience of kidney disease. (p. 166)

Moreover, Rose focused on her affinity for autoethnography because of its potential to redress hermeneutic injustice by providing space for stories of the marginalized, the unspoken and the unheard. Rose considered how autoethnography allowed her a way of communicating her lived experiences to an audience that most likely has not experienced kidney disease. She also conceded how, in so doing, she had to confront some of her biases and her collusion in her own victimization. To conclude, Rose put forward that autoethnography can play an important ethical role in South African academia in terms of "witnessing, exploring issues of social justice and social change, for knowing what it is like" (2016, p. 171).

After having re-read the autoethnographies by Delysia, Robert, and Rose, we went on to create a poem from each. Our intention was for these poems to serve as research poems that, as Langer and Furman (2004) explained, can be used to offer a concise and vivid representation of research data (in this case, we viewed the three autoethnographic texts as research data). The emphasis in our collective poetry making was not on creating poems that would demonstrate a high level of artistic or literary merit; rather, we anticipated that the act of creating this research poetry would deepen our learning (Langer \& Furman, 2004) about multiculturalism and equity through dialoguing with Delysia's, Robert's, and Rose's stories of lived experience.

We decided to use the Japanese tanka poem format (Furman \& Dill, 2015) to guide us in generating the three research poems. By drawing on a literary style from Japan, we were enacting multiculturalism by valuing and bringing into dialogue diverse cultural heritages. In composing our tankas, we used a version of the tanka format that has five lines, with a 5/7/5/7/7 syllable count in the lines (Poets.org, 2004b). We followed the traditional configuration of the tanka, which reveals an evolution from observing an image in the first two lines to exploring a personal response in the two closing lines, with the third line marking the beginning of that evolution (Poets.org, 2004b).

By using the tanka format, we hoped to be able to distil and express our learning from reading the three autoethnographies (Furman \& Dill, 2015). The tanka seemed an appropriate poetic mode for learning from the autoethnographies because, as Breckenridge (2016) explains, it is a poetic form that "is concerned primarily with...conveying an authentic, personal voice" and is often used in contemporary literature "to address difficult or hidden social issues" (p. 4).

We created one tanka from each autoethnography by choosing significant words and phrases from the texts written by Delysia, Robert, and Rose and repositioning these words and phrases into poetic form (Butler-Kisber, 2002). The dense structure of the 
tanka format meant that we could create only five short lines from each text. We worked interactively and meticulously with the tankas in our struggle to recognize and communicate our learning in dialogue with the voices of Delysia, Robert, and Rose (Furman, Langer, Davis, Gallardo, \& Kulkarni, 2007). Typing in a MS Word document that was projected onto a screen helped us to see the growth of each co-composed poem. We shaped and reshaped each tanka by trying out different configurations of words and phrases taken from the respective autoethnographic text.

\title{
The Three Tanka Poems
}

\section{Retracing Brokenness to Be Self-resilient}

- Inspired by the words of Delysia Norelle Timm

\author{
Uncovering pain \\ Retracing brokenness \\ I observed my self \\ I had to take a deep risk \\ To be self-resilient
}

\section{Constricted, Tenuous, Ambiguous}

- Inspired by the words of Robert J. Balfour

Spaces constricted

Identity tenuous

Transforming the text

Nuancing difference... Safe?

Ambiguous disclosure

\section{A Fragmentary, Challenging Story}

- Inspired by the words of Rose Richards

Long-term survivor

Voices of experience

Never walk away

A fragmentary story

Challenging the status quo

After crafting the individual research poems (the three tankas), we decided to use these as material for a fourth poem that would bring together the previous three poems. We chose a renga format for this poem. The renga is a form of linked-verse Japanese 
poetry usually composed by two or more poets as a means of dialoguing with each other (Poets.org, 2004a). The first stanza of a renga, with three lines in a 5/7/5 syllable count, is typically composed by one poet and the subsequent stanza, with two lines in a $7 / 7$ syllable count, is typically created by another poet in response to the first stanza. The third stanza repeats the structure of the first and the fourth repeats the second, alternating in this pattern until the poets have concluded their poetic dialogue. In our case, we worked together to compose each of the four stanzas of our renga, while still attempting to create a dialogue between the stanzas and a sense of dialogic progression all through the poem. We saw the renga as suitable for our fourth poem because of its potential for evoking dialogue "through the 'interillumination' or 'interanimation'... of diverse voices" (Pithouse-Morgan et al., 2014, p. 152). We understood our renga to be positioned in and created by the dynamic space between the voices of Delysia, Robert and Rose and our own reading of their words.

\title{
The Renga Poem
}

\author{
Nuancing, Transforming \\ - Dialoguing with the words of Delysia Norelle Timm, Robert J. Balfour, and \\ Rose Richards
}

\author{
Ambiguous space \\ Identity tenuous \\ Voices constricted \\ A fragmentary story \\ Pain and brokenness \\ I observe my self \\ Nuancing experience \\ I risk disclosure
}

Transforming the status quo

A deep, long-term difference

\section{Reflexive Dialoguing with the Renga Poem}

After composing the renga, we met again several times to discuss our learning in relation to this poem, and we audio-recorded these conversations. The audio recordings revealed how engaging with the three autoethnographies through a poetic lens brought us closer to Delysia's, Robert's and Rose's lived experiences of marginalization and discrimination. In our discussions, there was a slippage between "us" and 'them" as their stories and ours became entangled. 
We decided to compose a series of brief reflexive dialogues using excerpts from the transcripts of our audio-recorded conversations. In this way we combined two alternative research practices to enact our autoethnographic inquiry: collective poetry making and reflexive dialogue (Pithouse-Morgan \& Van Laren, 2012; Pithouse-Morgan et al., 2015). We anticipated that "using two different methods [would allow us] to present a more complex and complete account" of our collective learning (Furman, 2005 , p. 28). We were building on the work of autoethnographic researchers who argued for the use of reflexive dialogue as a means to negotiate meaning and to represent and understand this negotiation in action during a collective autoethnographic inquiry (e.g., Coia \& Taylor, 2009; Johnston, \& Strong, 2008). We wanted to use dialogue to demonstrate and consider how we had "talked our way forward" (Johnston \& Strong, 2008, p. 49).

Kathleen began the process of developing the dialogues by listening again to and transcribing the audio recordings of our conversations about the renga. She then clustered excerpts from the transcripts into a sequence of brief dialogues that responded to the different stanzas of the renga. Kathleen edited these excerpts to facilitate flow and coherence and then shared the dialogues with Inbanathan and Daisy for further refining.

\section{The Reflexive Dialogue Sequence}

\section{Renga Stanza 1: Ambiguous Space I Identity Tenuous I Voices Constricted}

Kathleen: I think that reading Delysia, Robert, and Rose's stories brought their diverse experiences of being "othered" into our direct, felt experience. It helped us to feel how, when they see themselves as deficit or less than, there is a fear of being seen as somebody who is weak.

Daisy: We don't talk about it - that lived experience of feeling weak. It's almost as if it should be hidden somewhere, it shouldn't be visible. Autoethnography provides a space to dialogue with that feeling.

Inbanathan: It's about shifting the gaze inwards.

Daisy: Autoethnography provides processes for doing that.

Kathleen: And space and time to do that.

\section{Renga Stanza 2: A Fragmentary Story I Pain and Brokenness}

Daisy: You see the pain in these autoethnographies; I think of Delysia the most. Through autoethnography, the pain and brokenness that was always there becomes nuanced when she reads her lived experience in relation to outside forces. 
Kathleen: Her story shows that it is freeing when we realize that our feelings of fear or pain are perfectly comprehensible responses to what is happening around us. When we realize this, we can stop being so self-judgmental.

Daisy: Stop punishing ourselves.

Inbanathan: So, we're saying that writing autoethnography is self-transformative?

Kathleen: It's self-transformative, but the self-transformation then makes a long term difference to the way in which we are able to engage with others.

Daisy: It makes us realize that these constant negotiations are everyday situations. They're not once off big events. They are part of our everyday life.

Kathleen: So it's how we learn to live with those tensions and constrictions, to start authoring our own stories.

Daisy: But remember, this transforming is ongoing. That's what makes us living beings - that ongoing dialogue.

\section{Renga Stanza 3: I Observe Myself I Nuancing Experience I I Risk Disclosure}

Daisy: So, for Delyisa, Robert, and Rose, through autoethnography, they each found a space to dialogue with themselves.

Kathleen: But not just with themselves. Because autoethnography is made public, it invites other people into that dialogue. It takes on a life of its own with everybody who reads it thereafter. Reading autoethnographies allows us to see through a lens of multiple selves.

Inbanathan: As Rose said in her autoethnography, it's important to know what and it's important to know how, but it's more important to know what it is like to be in that situation.

Daisy: The methodology then becomes the source for that engagement. It's not only dialogue with self but also dialoguing with others.

Inbanathan: So, autoethnography is a humanizing methodology. But, how does that humanizing methodology link to multiculturalism?

Kathleen: Autoethnography is also a dialogue with culture. I think it can illuminate multiculturalism as a multifaceted, complex, nuanced concept. And autoethnography shakes up the idea of equity. Equity is not only about certain categories. Equity is about lived experience of human beings in a particular space. You start to feel the lack of equity.

Daisy: That lack of equity is disconnecting one human being from another.

Kathleen: And, by engaging with the three autoethnographies through a poetic lens -

Daisy: What's happening to us as readers and writers? 
Inbanathan: We've become entangled in the process.

Kathleen: It is about us and about them - it's both. When you construct a poem, it says as much about you the poet as it does about your subject.

Daisy: To what extent do we change? Do our ideas of equity start to change?

Inbanathan: They've already changed. We're coming to know those lived experiences. We're getting to know what it is like to live those lives. It's through this that we can connect with our students and our colleagues as well.

Kathleen: There's that idea of an ethic of care in academia.

Daisy: That ethic of care is when we care enough to say, "We need to change; we need to open and deepen our understandings." Only when we start doing that, can an ethic of care start to happen. It's when we say, "I really need to care about what my limits are first and care enough to change that."

\section{Renga Stanza 4:}

\section{Transforming the Status Quo I A Deep, Long-term Difference}

Kathleen: I think that what we're saying is that, as academics, before we can teach anyone else about multiculturalism and equity, we need to go beyond our own limits. So, there's the process of transforming ourselves, the need to walk our talk. But also, are there implications for how we would engage with issues of multiculturalism and equity in our own classrooms?

Inbanathan: Absolutely. For example, Robert's autoethnography will be one of the readings that I will include in my Leadership courses. It gives a different perspective on leadership and marginalization.

Kathleen: And yet, there could be resistance from many students to even reading Robert's autoethnography, let alone engaging with it. So, what would you do to encourage them to engage with the autoethnography? Would you do something similar to our process?

Inbanathan: Definitely, because, through our own poetic inquiry, we saw how, in order to experience what Robert went through, engaging in the creation of found poems and dialoguing can be quite rich. But, how is it that we were able to create this space where we could dialogue?

Kathleen: What really brought us together is our interest in creative and selfreflexive methodologies. I suppose then, there was already an element of risktaking and a willingness to search, to go beyond our own limits.

Daisy: For me, that's the starting point.

Kathleen: There also has to be trust. It's a symbiotic process. We get drawn together through our mutual interest and then through exploring that interest, trust, understanding and care can grow. 
Daisy: Because of this prolonged, interactive, caring engagement, it becomes another way to look at the world.

Kathleen: And that's what we want to cultivate in our classrooms.

\section{Composing an Interpretive Poem}

Creating the reflexive dialogue sequence provided us with material for composing an additional, interpretive poem. Langer and Furman (2004) explain that the purpose of interpretive poetry is to move beyond representing research data in order to create poetry "which allows for the subjective responses of the researchers" (para. 16). We created the following tanka poem to crystallize our emerging learning about the potential of collective poetic autoethnographic inquiry to create spaces for dialoguing with multiculturalism and equity.

\section{A Dialogue Space}

A dialogue space

Dialogue with selves and others

Shakes up being 'weak'

A lens of multiple selves

Dialoguing with culture

The first two lines of the tanka, "A dialogue space / Dialogue with selves and others," represent an invitational dialogue space that stems from and generates care for self and others. These lines portray the promise of collective poetic autoethnographic inquiry to open up spaces for dialoguing with multiculturalism and equity. For us, as academics, such dialoguing takes place in response to a context of constraining conditions produced by a global corporate managerial reculturing of universities, which serves to disembody and disconnect human beings in academia as units arranged hierarchically (Burns, 2015; Eagleton, 2015). Like their global counterparts, South African universities are becoming more and more business-like in their day-to-day operations, with a focus primarily on efficiency, accountability, and performance (Clare \& Sivil, 2014; Maistry, 2015). In reducing academia to a market commodity, academic departments are being turned into business entities where academic work is "managed through strategic control" and there is a strong "focus on outputs which can be quantified and compared" (Reid, 2009, p. 575). This reculturing of universities is antithetical to the ethical, dialogical imperative to cultivate multiculturalism and equity in universities, with corporate managerial reforms constraining "access and opportunity along class and racial lines," including "reduced government support to institutions and individuals" (Torres, 2011, p. 177). Even when universities and governments espouse multiculturalism and equity, in practice this is often reduced to numerical targets that 
can be easily measured and used to satisfy short-term performance management criteria, while marginalising long-term social justice goals (Mok, 1999).

This brings us to the pivotal third line of our tanka: "Shakes up being 'weak."' This line shows a movement from an examination of the image of a dialogue space to an examination of our personal response. "Being "weak" relates to tensions we saw in the autoethnographic accounts of Delsyia, Robert, and Rose negotiating their academic lives and work, within and in response to conditions created by marginalization and discrimination. Such tensions do not seem to be unique to a South African academic context. International scholars have highlighted a range of often incapacitating tensions that academics encounter in navigating a corporate managerial reculturing that positions individuals, academic departments, and institutions as competitors rather than colleagues (Blom, Bennett, \& Wright, 2011; Charteris, Gannon, Mayes, Nye, \& Stephenson, 2015; Giroux, 2013). These tensions, which are often exacerbated by inadequate institutional and collegial support, can give rise to feelings of anxiety, insecurity, and unworthiness among academics, especially among early career academics and those who have experienced marginalization and exclusion (Archer, 2008; Bertrand Jones, Wilder \& Osborne-Lampkin, 2013; Lechuga 2012).

Feelings of being weak and the fear of being seen as weak can bring about high levels of stress for academics, which can take a toll on their long-term psychological and physical health, as well as their work satisfaction and performance (Barkhuizen \& Rothmann, 2008; Mark \& Smith 2012; Watts \& Robertson, 2011). In thinking about this, we were interested to discover that the etymological roots of the word "weak" have connotations of being "pliant" and able "to bend" (weak, n.d.). This third line therefore is about reclaiming the idea of being weak in a more positive light by understanding weakness as capacity for malleability, suppleness, and growth. In this sense, acknowledging our human weakness means that we can reconsider ourselves as contingent and changing; we can be flexible; we can shift our perspectives. An awareness of the impermanence of lived experience and of our human capacity for negotiation can generate hopefulness and possibilities, which are crucial to the ethical project of multiculturalism and equity.

The closing lines of the tanka, "A lens of multiple selves / Dialoguing with culture," bring to light our learning about and through cultivating generative conditions in which we can be open to moments of "knowing what it is like" (Richards, 2016, p. 171) from multiple vantage points. Here, we are thinking about Erikson's (1963) conception of generativity, which comprises "creativity and a calling to contribute to the well-being of others" (Pithouse-Morgan \& Van Laren, 2012, p. 417). This invitation to "depict individuals as capable of working on themselves to achieve new kinds of existence" (Allan, 2013, p. 29), rather than waiting for a "more substantial structural or material change, is an ethico-political choice" (Foucault, 1984, p. 343). An expressive, creative, "co-flexive" (collectively reflexive) methodology such as collective poetic autoethnographic inquiry can facilitate encountering lived experience spaciously and with a heightened sense of possibilities (Pithouse-Morgan et al., 2015, p. 167). Critical multicultural insights can emerge and can be developed through dialogue and in community to give a sense of orientation and direction to ethical practice within and beyond academia. Dialoguing with culture involves working with difficult tensions to 
make ethical choices, but it can also bring about collective curiosity and joy that can sustain us (Harrison et al., 2012).

\section{Closing}

How might this account of our collective poetic autoethnographic inquiry potentially benefit others? Methodologically, we have attempted to write this article in a translucent and expressive way so that it shows rather than just tells about our coflexive process. We hope it will serve as an accessible resource for others who are interested in collaborative and creative approaches in self-reflexive research. In addition, we offer our learning about how poetry and dialogue can facilitate a generative entanglement with autoethnographies written by others. Poetic dialoguing with our insights in relation to the others' stories of experience "evokes the care of what exists and might exist" (Foucault, 1988, p. 328). The collective and creative practice of an ethic of relationality, dialogue, and care has potential to make a deep and long-term difference with respect to walking our talk of multiculturalism and equity in our classrooms and through our interactions with students and colleagues.

Our collective poetic autoethnographic inquiry was about recognizing our common humanity. In our understanding, "to be human means to be in dialogue - with others, with oneself and with the world" (Rule, 2015, p. xix). As the Southern African ethical philosophy of ubuntu reminds us, we are relational beings. Through a collective poetic process, this relationality was illuminated as the power of being in dialogue provided means for our collective learning.

\section{Acknowledgements}

1. We are grateful to Lesley Scott of George Mason University, USA, for introducing us to renga poetry.

2. We thankfully acknowledge funding from a University Teaching and Learning Office (UTLO) Institutional Research Grant for our project: Academic Autoethnographies.

3. We appreciate the insightful feedback from the editors and peer reviewers of this special issue.

\section{Notes}

1. The tanka is a traditional Japanese poetic form, often consisting of five lines with a 5/7/5/7/7 syllable count (Poets.org., 2004b).

2. The renga is a form of linked-verse Japanese poetry, which is usually composed by two or more poets (Poets.org., 2004a). 


\section{References}

Allan, J. (2012). Foucault and his acolytes: Discourse, power and ethics. In M. Murphy (Ed.), Social theory and education research: Understanding Foucault, Habermas, Bourdieu and Derrida (pp. 21-34). London, UK: Routledge.

Archer, L. (2008). Younger academics' constructions of 'authenticity', 'success' and professional identity. Studies in Higher Education, 33(4), 385-403.

Balfour, R. J. (2016). The (in)visible gay in academic leadership: Implications for reimagining inclusion and transformation in South Africa. In D. Pillay, I. Naicker, \& K. Pithouse-Morgan (Eds.), Academic autoethnographies: Inside teaching in higher education (pp. 133-147). Rotterdam, NL: Sense.

Barkhuizen, N., \& Rothmann, S. (2008). Occupational stress of academic staff in South African higher education institutions. South African Journal of Psychology, 38(2), 321-336.

Bertrand Jones, T., Wilder, J., \& Osborne-Lampkin, L. T. (2013). Employing a Black feminist approach to doctoral advising: Preparing Black women for the professoriate. Journal of Negro Education, 82, 326-338.

Blom, D., Bennett, D., \& Wright, D. (2011). How artists working in academia view artistic practice as research: Implications for tertiary music education. International Journal of Music Education, 29(4), 359-373.

Breckenridge, J. P. (2016). The reflexive role of tanka poetry in domestic abuse research. Journal of Research in Nursing, 1-14.

Burns, J. (2015). The moral bankruptcy of corporate education. Teachers College Record, ID Number: 18091. Retrieved from http://www.tcrecord.org/ Content.asp?ContentID=18091

Butler-Kisber, L. (2002). Artful portrayals in qualitative inquiry: The road to found poetry and beyond. Alberta Journal of Educational Research, 48(3), 229-239.

Chang, H. (2008). Autoethnography as method. Walnut Creek, CA: Left Coast Press.

Chang, H., Ngunjiri, F., \& Hernandez, K.-A. C. (2013). Collaborative autoethnography. Walnut Creek, CA: Left Coast Press.

Charteris, J., Gannon, S., Mayes, E., Nye, A., \& Stephenson, L. (2015). The emotional knots of academicity: A collective biography of academic subjectivities and spaces. Higher Education Research \& Development, 1-14.

Clare, J., \& Sivil, R. (2014). Autonomy lost. The bureaucratisation of South Africa HE. South African Journal of Higher Education, 28(1), 60-71.

Clarke, N. L., \& Worger, W. H. (2016). South Africa: The rise and fall of apartheid (3rd ed.). Abingdon, UK: Routledge. 
Coia, L., \& Taylor, M. (2009). Co/autoethography: Exploring our teaching selves collaboratively. In D. Tidwell, M. Heston, \& L. Fitzgerald (Eds.), Research methods for the self-study of practice (pp. 3-16). New York, NY: Springer.

Timm, D. N. (2016). From exclusion through inclusion to being in my element: Becoming a higher education teacher across the apartheid-democratic interface. In D. Pillay, I. Naicker, \& K. Pithouse-Morgan (Eds.), Academic autoethnographies: Inside teaching in higher education (pp. 95-115). Rotterdam, NL: Sense.

Eagleton, T. (2015). The slow death of the university. The Chronicle Review. The Chronicle of Higher Education, 1-11. Retrieved from http://chronicle.com/ article/TheSlowDeathofthe/228991/?cid=cr\&utm_source=cr\&utm_medium=en

Erikson, E. H. (1963). Childhood and society (2nd ed.). New York, NY: W. W. Norton \& Company (Original work published 1950).

Foucault, M. (1984). On the genealogy of ethics: An overview of work in progress. In P. Rabinow (Ed.), The Foucault Reader (pp. 340-372). New York, NY: Pantheon.

Foucault, M. (1988). The masked philosopher. In L. Kritzman (Ed.), Michael Foucault: Politics, philosophy, culture. Interviews and other writings (pp. 323-330). London, UK: Routledge.

Furman, R. (2005). Autoethnographic poems and narrative reflections: A qualitative study on the death of a companion animal. Journal of Family Social Work, 9(4), 23-38.

Furman, R., Langer, C. L., \& Taylor, D. B. (2010). Analyzing narratives through poetic forms and structures in gerontology: Applying new tools in qualitative research. Journal of Poetry Therapy, 23(2), 61-71.

Furman, R., \& Dill, L. (2015). Extreme data reduction: The case for the research tanka. Journal of Poetry Therapy, 28(1), 43-52.

Furman, R., Langer, C. L., Davis, C. S., Gallardo, H. P., \& Kulkarni, S. (2007). Expressive, research and reflective poetry as qualitative inquiry: A study of adolescent identity. Qualitative Research, 7(3), 301-315.

Giroux, H. A. (2013). Public intellectuals against the neoliberal university. Truth Out. Retrieved from http://truth-out.org/opinion/item/19654-public-intellectuals-againstthe-neoliberal-university

Grant, A., Short, N. P., \& Turner, L. (2013). Introduction: Storying life and lives. In N. P. Short, L. Turner, \& A. Grant (Eds.), Contemporary British autoethnography (pp. 1-16). Rotterdam, NL: Sense Publishers.

Haarhoff, D. (1998). The writer's voice: A workbook for writers in Africa. Halfway House, Midrand, ZA: Zebra Press.

Harrison, L., Pithouse-Morgan, K., Conolly, J., \& Meyiwa, T. (2012). Learning from the first year of the Transformative Education/al Studies (TES) project. Alternation, 19(2), 12-37. 
Johnston, D. N., \& Strong, T. (2008). Reconciling voices in writing an autoethnographic thesis. International Journal of Qualitative Methods, 7(3), 48-61.

Lahman, M. K. E., Geist, M. R., Rodriguez, K. L., Graglia, P. E., Richard, V. M., \& Schendel, R. K. (2010). Poking around poetically: Research, poetry, and trustworthiness. Qualitative Inquiry, 16(1), 39-48.

Langer, C., \& Furman, R. (2004). Exploring identity and assimilation: Research and interpretive poems. Forum Qualitative Sozialforschung / Forum: Qualitative Social Research, 5(2), Article 5. Retrieved from http://www.qualitativeresearch.net/index.php/fqs/article/view/609

Lechuga, V. M. (2012). Emotional management and motivation: A case study of underrepresented faculty. New Directions for Institutional Research, 155, 85-98.

Maistry, S. (2015). Accountability and surveillance: New mechanisms of control in higher education. Transformation, 88, 25-35.

Mark, G., \& Smith, A. P. (2012). Effects of occupational stress, job characteristics, coping, and attributional style on the mental health and job satisfaction of university employees. Anxiety, Stress, \& Coping, 25(1), 63-78.

Mitchell, C. (2016). Autoethnography as a wide-angle lens on looking (inward and outward): What difference can this make to our teaching? In D. Pillay, I. Naicker, \& K. Pithouse-Morgan (Eds.), Academic autoethnographies: Inside teaching in higher education (pp. 175-189). Rotterdam, NL: Sense Publishers.

Mkhize, N. (2004). Psychology: An African perspective. In K. Ratele, N. Duncan, D. Hook, N. Mkhize, P. Kiguaw \& A. Collins (Eds.), Self, community \& psychology (pp. 4-1-4-29). Lansdowne, Cape Town, ZA: UCT Press.

Mok, K. H. (1999). The cost of managerialism: The implications for the 'McDonaldisation' of higher education in Hong Kong. Journal of Higher Education Policy \& Management, 21(1), 117-128.

Pillay, D., Naicker, I., \& Pithouse-Morgan, K. (Eds.). (2016a). Academic autoethnographies: Inside teaching in higher education. Rotterdam, NL: Sense Publishers.

Pillay, D., \& Pithouse-Morgan, K. (2016). A self-study of connecting through aesthetic memory-work. In J. Kitchen, D. Tidwell, \& L. Fitzgerald (Eds.), Self-study and diversity II: Inclusive teacher education for a diverse world (pp. 121-136). Rotterdam, NL: Sense Publishers.

Pithouse-Morgan, K., Muthukrishna, N., Pillay, D., Van Laren, L., Chisanga, T., Meyiwa, T., Moletsane, R., Naicker, I., Singh, L., \& Stuart, J. (2015). Learning about coflexivity in a transdisciplinary self-study research supervision community. In K. Pithouse-Morgan \& A. P. Samaras (Eds.), Polyvocal professional learning through self-study research (pp. 145-171). Rotterdam, NL: Sense Publishers.

Pithouse-Morgan, K., Naicker, I., Chikoko, V., Pillay, D., Morojele, P., \& Hlao, T. (2014). Entering an ambiguous space: Evoking polyvocality in educational research through collective poetic inquiry. Perspectives in Education, 32(4), 149-170. 
Pithouse-Morgan, K., Naicker, I., Pillay, D., Masinga, L., \& Hlao, T. (2016). 'Sink or swim?': Learning from stories of becoming academics within a transforming university terrain. South African Journal of Higher Education, 30(1), 1-20.

Pithouse-Morgan, K., \& Van Laren, L. (2012). Towards academic generativity: Working collaboratively with visual artefacts for self-study and social change. South African Journal of Education, 32(4), 416-427.

Poets.org. (2004a). Poetic form: Renga. Retrieved from https://www.poets.org/ poetsorg/text/poetic-form-renga

Poets.org. (2004b). Poetic form: Tanka. Retrieved from http://www.poets.org/ poetsorg/text/poetic-form-tanka

Reddy, V., Meyer, S., Shefer, T., \& Meyiwa, T. (2014). Towards a critical theory of care. In V. Reddy, S. Meyer, T. Shefer, \& T. Meyiwa (Eds.), Care in Context: Transnational gender perspectives (pp. 1-27). Cape Town, ZA: HSRC Press.

Reid, I.C. (2009). The contradictory managerialism of university quality assurance. Journal of Education Policy, 24(5), 575-593.

Richards, R. (2016). Subject to interpretation: Autoethnography and the ethics of writing about the embodied self. In D. Pillay, I. Naicker, \& K. Pithouse-Morgan (Eds.), Academic autoethnographies: Inside teaching in higher education (pp. 163-174). Rotterdam, NL: Sense.

Rule, P. (2015). Dialogue and boundary learning. Rotterdam, NL: Sense.

South African Human Rights Commission. (2012). South African Human Rights Commission equality report: Commentaries on equality: Race, gender, disability and LGBTI issues Retrieved from http://www.sahrc.org.za/home/21/files/ Equality\%20Report\%2020\%200ct\%202012\%20Final.pdf

Timm, D. (2016). From exclusion through inclusion to being in my element: Becoming a higher education teacher across the apartheid-democratic interface. In D. Pillay, I. Naicker, \& K. Pithouse-Morgan (Eds.), Academic autoethnographies: Inside teaching in higher education (pp. 95-115). Rotterdam, NL: Sense.

Torres, CT. (2011). Public universities and the neoliberal common sense: Seven iconoclastic theses. International Studies in Sociology of Education, 21(3), 177197.

Van Laren, L., Pithouse-Morgan, K., Chisanga, T., Harrison, L., Meyiwa, T., Muthukrishna, N., Naicker, I., \& Singh, L. (2014). 'Walking our talk': Exploring supervision of postgraduate self-study research through metaphor drawing. South African Journal of Higher Education, 28(2), 639-659.

Watts, J., \& Robertson, N. (2011). Burnout in university teaching staff: A systematic literature review. Educational Research, 53(1), 33-50.

Weak. (n.d.) In The Online Etymology Dictionary. Retrieved from http://www. etymonline.com/index.php?term=weak 


\section{Author Contact}

Kathleen Pithouse-Morgan: pithousemorgan@ukzn.ac.za

University of KwaZulu-Natal, School of Education, Teacher Development Studies, Edgewood Campus, Office No. CS123, Durban 4041, South Africa

Inbanathan Naicker: naickeri1@ukzn.ac.za

University of KwaZulu-Natal, School of Education, Teacher Development Studies, Edgewood Campus, Office No. G313, Durban 4041, South Africa

Daisy Pillay: pillaygv@ukzn.ac.za

University of KwaZulu-Natal, School of Education, Teacher Development Studies, Edgewood Campus, Office No. CS120, Durban 4041, South Africa 